Volume 13

Issue 3 Critical Genocide and Atrocity

Prevention Studies

$12-20-2019$

\title{
Film review: The Trial of Ratko Mladić
}

Iva Vukušić

Utrecht University, Department of History and Art History

Follow this and additional works at: https://digitalcommons.usf.edu/gsp

\section{Recommended Citation}

Vukušić, Iva (2019) "Film review: The Trial of Ratko Mladić," Genocide Studies and Prevention: An International Journal: Vol. 13: Iss. 3: 181-184.

DOI:

https://doi.org/10.5038/1911-9933.13.3.1661

Available at: https://digitalcommons.usf.edu/gsp/vol13/iss3/20

This Film Review is brought to you for free and open access by the Open Access Journals at Digital Commons @ University of South Florida. It has been accepted for inclusion in Genocide Studies and Prevention: An International Journal by an authorized editor of Digital Commons @ University of South Florida. For more information, please contact digitalcommons@usf.edu. 
Film Review: The Trial of Ratko Mladić

\author{
Iva Vukušić \\ Utrecht University \\ Utrecht, Netherlands
}

The Trial of Ratko Mladić

Directors: Henry Singer, Rob Miller

United Kingdom, 2018

Reviewed by Iva Vukušić

Utrecht University

A myriad of films about conflicts and atrocities, war crimes and war crimes trials are made each year. Some of them are feature films, and some are documentaries. One of those documentaries is The Trial of Ratko Mladić, premiered in November 2018 at the International Documentary Film Festival in Amsterdam. It is a thorough, accurate, multidimensional and nonmanipulative account of one of the biggest war crimes trials in history. As such, it speaks to at least three audiences: those interested in the former Yugoslavia, those interested in war crimes trials and judicial responses to mass violence, and those interested in perpetrators and perpetration of mass violence.

Ratko Mladić, the Bosnian Serb general who commanded the Bosnian Serb Army (Vojska Republike Srpske, VRS) for the duration of the Bosnian War (1992-1995) was first indicted in 1995, by the Prosecutor of the International Criminal Tribunal for the former Yugoslavia (ICTY) in The Hague. ${ }^{1}$ The ICTY was established in 1993 by the United Nations Security Council to hold those most responsible for genocide, crimes against humanity and war crimes accountable. It was an international court, dependent on state cooperation to make arrests. When Mladić was indicted in 1995, alongside Radovan Karadžić, the President of Republika Srpska, a statelet that was being built through violence and expulsion, there was no political will to make the arrests. Mladić was finally apprehended in 2011, in a small village in a northern province in Serbia, in bad health, hiding with relatives. In December 2017, the ICTY closed, just weeks after pronouncing Mladic guilty and sentencing him to life imprisonment. The case is currently on appeal and scheduled to be completed in $2020 .^{2}$

Mladić was charged for a large set of incidents relating to: 1.) the violent campaign Bosnian Serb forces engaged in in the spring and summer 1992, resulting in the death, torture, rape and expulsion of thousands of non-Serbs from large areas of Bosnia and Herzegovina, 2.) siege of Sarajevo, 3.) genocide after the fall of Srebrenica, and 4.) the hostage-taking of UN blue helmets. ${ }^{3}$ It was a huge case, years and years in the making, as prosecutors painstakingly worked on lowerlevel perpetrators, civilian, military, and paramilitary. The ICTY indicted 161 individuals and convicted 89. A number were army officers. For example, the Popović et al., and Tolimir cases dealt with Mladićs subordinates during and after the fall of Srebrenica. Those cases helped lay the groundwork for the Mladic trial, both in terms of practice i.e. how to conduct and manage a large case, and in terms of content - the evidence - what is that essential proof that needs to be presented by the prosecution to prove a case beyond a reasonable doubt.

This documentary focused on the genocide component of the case, which is understandable given the size of the trial. It would have been very difficult to tell the story of the entire trial in any meaningful way in 90 minutes or so, because the court heard almost 600 witnesses, accepted tens of thousands of pages of documents into evidence and produced a record so large that it would take one individual several years to study it thoroughly. Therefore, the majority of the documentary

\footnotetext{
${ }^{1}$ International Criminal Tribunal for the former Yugoslavia, "Milan Martic, Radovan Karadzic and Ratko Mladic indicted along with 21 other accused," press release, July 25, 1995, accessed December 13, 2018, http://www.icty.org/en/press/ milan-martic-radovan-karadzic-and-ratko-mladic-indicted-along-21-other-accused.

${ }^{2}$ MICT, Prosecutor v. Ratko Mladic MICT-13-56, accessed December 13, 2018, http://www.irmct.org/en/cases/mict-13-56.

${ }^{3}$ ICTY, Prosecutor v. Ratko Mladic IT-09-92, accessed December 13, 2018, http://www.icty.org/case/mladic/4.
} 
deals with Srebrenica, the only set of incidents the ICTY entered convictions for genocide, ${ }^{4}$ and Prijedor. The latter is likely less familiar to readers, even though for those who study the former Yugoslavia, it is well known as a town in north-western Bosnia where the violent campaign to take over municipalities in early 1992 led to mass victimization, detention in camps such as Omarska, Trnopolje and Keraterm, and led to drastic demographic changes and the virtual disappearance of non-Serb communities. As in the Karadžić case, ${ }^{5}$ the prosecutor has attempted to prove that events in Prijedor and a set of other municipalities in 1992 were so drastic, so violent and so systematic that they have reached the threshold where they should be considered genocide. The trial judges ruled, in both Karadžić and Mladić that they were not convinced that threshold has been reached. Mladić was however convicted for extermination, persecution, murder, and forcible transfer of non-Serbs from that area. Both cases are currently on appeal. ${ }^{6}$

This documentary is a product of a long-lasting dedication, study and a clear-headed approach. Often enough, documentarians take on, out of the noblest motives, complex trials to depict without dedicating enough time to understand how trials work. Sometimes they get carried away and depict how atrocities take place in black-and-white simplistic narratives and make perpetrators almost cartoonish caricatures, evil to the point where the audience has an easy job, to sit back and judge. This is not the case here. The film draws heavily upon the work of individuals with expertise and does not make mistakes that may pass by unnoticed by most, but that would irritate those that spend their lives observing these trials. This documentary is serious, does not take cheap shots to make grandiose moral points, and is balanced: listening to both prosecutors and defense counsel, survivors and Mladić's family members. Importantly, at the premiere in Amsterdam, in the $\mathrm{Q}$ and $\mathrm{A}$, members of the prosecution and defense were there, and showed support for the film.

What we know about the details of these atrocities in the former Yugoslavia, we know largely because of trials. Millions of documents, almost five thousand witnesses, years of court proceedings enabled us to have the biggest, most thorough collection of material about the war in the former Yugoslavia in the ICTY archives. ${ }^{7}$ Amazingly, the ICTY is the only war crimes court that provides extensive access to its evidence material. ${ }^{8}$ Of course, not everything is accessible, as some documentation and testimony remains confidential, but much is available, to everyone and for free. Those sources can be used for what Diane Orentlicher called "shrinking the space for denial." ${ }^{\prime 9}$ In the recent years, the interaction of history and war crimes trials has been investigated even more, ${ }^{10}$ and historians can benefit greatly from using these records. Historians have been central to ICTY cases, and one of them, Robert Donia, wrote a thorough political biography of Radovan Karadžić, based on Donia's expert testimony in over a dozen trials. ${ }^{11}$ At times, ICTY evidence had a deep impact, challenging long-held views about what really happened, such as in the case of the so-called Scorpions video. ${ }^{12}$

\footnotetext{
${ }^{4}$ Srebrenica - related cases can be explored here: http://www.icty.org/en/cases/interactive-map. An excellent overview of Srebrenica-related evidence can be found here: http://srebrenica.sense-agency.com/en/ Accessed December 132018.

${ }^{5}$ ICTY, Prosecutor v. Radovan Karadžić, IT-95-5/18, accessed December 13, 2018, http://www.icty.org/case/karadzic/4; MICT, Prosecutor v. Radovan Karadžić, MICT-13-55, accessed December 13, 2018, http://www.irmct.org/en/cases/ mict-13-55.

${ }^{6}$ More information available here: http://www.irmct.org/en/cases, accessed December 13, 2018.

${ }^{7}$ Iva Vukušić, "The Archives of the International Criminal Tribunal for the former Yugoslavia," History: The Journal of the Historical Association, 98, no. 332 (2013), 623- 635.

${ }^{8}$ United Nations, “ICTY Court Records database," accessed December 13, 2018, http://icr.icty.org/default.aspx.

${ }^{9}$ Diane Orentlicher, Some Kind of Justice: The ICTY's Impact in Bosnia and Serbia (Oxford: Oxford University Press, 2018).

${ }^{10}$ Richard Ashby Wilson, Writing History in International Criminal Trials (New York: Cambridge University Press, 2011).

${ }^{11}$ Robert Donia, Radovan Karadžić Architect of the Bosnian Genocide (Cambridge: Cambridge University Press, 2014).

${ }^{12}$ Iva Vukušić. "Nineteen Minutes of Horror: Insights from the Scorpions Execution Video”, Genocide Studies and
} 
The archival material the documentary uses, in combination with contemporary interviews, is an example of excellent use of evidence material. For example, images of Mladić in the aftermath of the fall of Srebrenica show an arrogant man clearly enjoying his victory. It is this kind of footage, which is juxtaposed to courtroom proceedings, and interviews with participants in the process: prosecutors and defense attorneys, Mladić's son, survivors whose families were wiped out. That is peppered with images of Mladić in the seventies, enjoying family holidays. One of the strongest points of the documentary was in how it treated one iconic image from the aftermath of the fall of Srebrenica. That is footage some readers may remember, of Ramo Osmanović, a man filmed on a meadow after capture as he was fleeing Srebrenica, calling loudly to his son and other Muslims to turn themselves in to Serb forces, telling them they will be fine. Ramo is etched in our memory as only that - a man on a meadow calling for others to surrender, thinking that is their best hope for survival. In fact, it wasn't. Ramo and his son Nermin were murdered and exhumed years later, in 2009, from two different mass graves: Nermin's remains were found in Snagovo close to Zvornik, and Ramo's in Zeleni Jadar, in the vicinity of Srebrenica. Both are now buried in Potočari memorial graveyard, across the road from where the UN was based in the protected area of Srebrenica.

In this documentary, what is shown through interviews with his wife who survived the war, and who testified at the ICTY, are two pictures: Pictures of Ramo and Nermin before the war. In that moment, the documentary reminds the viewer that even iconic images have backstories, and Ramo and Nermin had lives before that footage, lives that were cut short through the violence the trial tries to address. After seeing this film, the image of Ramo in our minds does not need to be only of a scared man on a meadow, who will soon be killed. We see Ramo in another light, and that is important. Ramo was a victim, but he was also much more than that.

What this film shows, albeit only subtly, is the extraordinary work so many people have done in order to conduct these investigations and hold these trials. Although he is in the film just for a moment, on a photograph, pictured standing next to a mass grave, it is worth mentioning the French investigator Jean-Rene Ruez who was in Tuzla just weeks after Srebrenica fell, looking for clues as to where the missing people were. He was the lead Srebrenica investigator for six years, seizing documents, interviewing perpetrators, survivors and family members, and searching for mass graves..$^{13}$ Who we do see is Eldar Jahić, an investigator with the Prosecutor's office in Sarajevo ${ }^{14}$, who spent months on the exhumation of the Tomašica mass grave close to Prijedor. Tomašica is one of the biggest mass graves in Bosnia, and Jahić spent months at the site, alongside colleagues, knee-deep in mud, rain or shine, coordinating the work of getting those decomposing bodies, hundreds of them, out of the ground, to get them cleaned, identified, and properly buried. Peter McCloskey, an American prosecutor, spent a decade prosecuting Srebrenica cases, one after another. McCloskey and his team were able to reconstruct what various actors did in the process of mass executions after the fall of Srebrenica, hour per hour. What these investigators, prosecutors and analysts did to prosecute and punish perpetrators and recover remains, is astounding, and was anything but easy. What we know about Srebrenica and other crimes, and we know a lot, is due to their work.

Finally, for those interested in the former Yugoslavia, there are several recent, or reasonably recent films, both documentaries and feature films, that touch upon some of the topics discussed in this review. First, one documentary and one feature film by the same author, Ognjen Glavonić, a young Serbian director. Depth Two is a documentary from a few years back, and it is notable for two reasons: it is very well researched and accurate, and it is both beautiful and poetic. The film

Prevention 12, no. 2 (2018), 35-53 accessed December 13, 2018, doi: 10.5038/1911-9933.12.2.1527; Ivan Zverzhanovski, "Watching War Crimes: The Srebrenica Video and the Serbian Attitudes to the 1995 Srebrenica Massacre," Southeast European and Black Sea Studies, 7, no. 3 (2007), 417-430; Vladimir Petrović, "A Crack in the Wall of Denial: The Scorpions Video in and out of the Courtroom," in Narratives of Justice In and Out of the Courtroom: Former Yugoslavia and Beyond, ed. Dubravka Žarkov and Marlies Glasius (New York: Springer, 2014), 89-110.

${ }^{13}$ International Commission on Missing Persons, "Latest Facts and Figures on Srebrenica," accessed December 132018 , https://www.icmp.int/news/infographic-provides-latest-facts-and-figures-on-srebrenica-genocide/.

${ }^{14}$ More about the work of the Prosecutor's Office of Bosnia and Herzegovina's Special Department for War Crimes available. Prosecutor's Office of Bosnia and Herzegovina, Special Department for War Crimes, accessed December 13, 2018, http://www.tuzilastvobih.gov.ba/?opcija=sadrzaj\&kat=2\&id=4\&jezik=e. 
deals with the operation to hide bodies of Kosovar Albanians killed by Serbian forces during the Kosovo war in 1998, and 1999. Glavonić's award-winning feature film, from 2018, The Load is an expansion on the topic of moving dead bodies in order to conceal the crime. The film is accurate, beautiful and moving. One feature film exploring the aftermath of violence from the perspective of the perpetrator and his family is Mirjana Karanović's A Good Wife. Karanović masterfully describes just how difficult it is to come to terms with the past in a society that does not want to do that. Finally, the feature Men don't cry, based on real-life attempts by civil society groups to try to help war veterans in Bosnia and Herzegovina live with their trauma. All these are exceptional contributions that bring nuance and humanity to thinking about the war in the former Yugoslavia. War is one of the most extreme experiences any person or any country can go through. These films, along with the documentary The Trial of Ratko Mladić successfully uncover this universal struggle, pain and difficulty of dealing with a violent past. Thus, for anyone interested in these processes, this is clearly a must-watch.

Title of the Film: The Trial of Ratko Mladic; Directors: Robert Miller, Henry Singer; Producers: Ida Bruusgaard, Jovo Martinovic; Cinematography: Richard Gillespie; Film Editor: Anna Price; Music: Anne Nikitin; Country: United Kingdom; Languages: English, Bosnian, Croatian; Year of Production: 2018; Production Company: Sandpaper Films; Duration: 99 minutes. 